\title{
The effectiveness comparison problem based learning model with NHT and TPS type on plane solid figure
}

\author{
Diana Amirotuz Zuraida ${ }^{1 *}$, Karyati Karyati ${ }^{2}$ \\ ${ }^{1}$ MAN Kota Surabaya. Jalan Wonorejo Timur No. 14, Kota Surabaya, Jawa Timur 60296, Indonesia. \\ ${ }^{2}$ Department of Mathematics Education, Universitas Negeri Yogyakarta. \\ Jalan Colombo No. 1, Karangmalang, Yogyakarta 55281, Indonesia. \\ * Corresponding Author. E-mail: diana.amirotuz@gmail.com \\ Received: 20 October 2017; Revised: 23 April 2018; Accepted: 31 December 2018
}

\begin{abstract}
The study was aimed to describe the learning model of problem based learning (PBL) with cooperative setting Numbered Heads Together (NHT) and Think Pair Share (TPS) type in terms of mathematics learning achievement, reflective thinking skills, and self regulated learning of junior high school $8^{\text {th }}$ grade students. The study was a quasi experimental research with pretest-posttest nonequivalent group design. The sample were taken at random from five classes, consisted of VIII-A and VIII-C. Data were analyzed by using multivariate statistical using Multivariate Analysis of Variance (MANOVA). The result of the study at 5\% level significance indicated that PBL with cooperative setting TPS type was effective in terms of reflective thinking skill; there was no difference of the effectiveness between PBL with cooperative setting NHT type and PBL with cooperative setting TPS type in terms of achievement, reflective thinking skills, and self-regulated learning of junior high school $8^{\text {th }}$ grade students.

Keywords: problem-based learning, mathematics learning achievement, reflective thinking skill, self-regulated learning

How to Cite: Zuraida, D., \& Karyati, K. (2018). The effectiveness comparison problem based learning model with NHT and TPS type on plane solid figure. Jurnal Riset Pendidikan Matematika, 5(2), 254-263. doi:htTPS://doi.org/10.21831/jrpm.v5i2.16444
\end{abstract}

Permalink/DOI: htTPS://doi.org/10.21831/jrpm.v5i2.16444

\section{INTRODUCTION}

Mathematics is one of study which was used in various sector. Nowadays, mathematics requires to adjust in the situation so that the change begins with mathematics instruction. According to Permendikbud 2016 number 21 mentions that in standard content, the students competencies that must be owned by showing the skills of reasoning and critical thinking (Kementerian Pendidikan dan Kebudayaan Republik Indonesia, 2016, p. 2).

Based on the competencies that required by students, the reasoning skills are related to the thinking skills. One of them is reflective thinking skill. Dewey (Fisher, 2009, p. 2) states that reflective thinking as an active activity, continuously, and thorough considering something that received from different perspectives and supported by a intense reasons. Reflective thinking will help students to determining the right decision or solution at problem solving.
Reflective thinking skill is the one of factors that influence student's achievement. The optimal achievement comes from a good instruction and supported by the ability of students in learning process. Mathematics achievement in high school is the ability and perception of students is interrelated variables for mathematic achievement in high school (Singh, Granville, \& Dika, 2002, p. 323). Dewey asserts that individuals will learn the knowledge and skills in certain condition, if the conditions can be adjusted appropiately. The learning process makes the experience and lesson for each individual constructing their intelligent thinking direction (Rodgers, 2002, p. 847).

Then, The National Council of Teachers of Mathematics defines that reflective thinking allows developing in classroom environment that supports students (National Council of Teachers of Mathematics, 2000, p. 54). Mezirow described that reflective thinking has four levels there are: (1) habitual action, regular activity routine, (2) 


\section{Jurnal Riset Pendidikan Matematika, 5 (2), 2018 - 255}

Diana Amirotuz Zuraida, Karyati Karyati

understanding for applying knowledge, (3) reflection which is considering the problem solving process and deciding the best solved, (4) critical reflection to evaluating ideas with the underlying reason (Angelique \& Lim, 2011, p. 173).

Weast (1996, p. 192) mentions that the definitions of reflective thinking there are: (1) identifying the author's assumptions, (2) identifying the causes and the evidence, (3) identifying unclear and ambiguous language, (4) identifying value assumptions, (5) identifying descriptive assumptions, (6) evaluating statistical analysis, (7) evaluating sampling and calculating, (8) evaluating logical reasoning, (9) identifying ignore information, and (10) Communicating individually in a considerate and objective.

The important role of reflective thinking is as a tool to encourage students during a problem solving situation because the reflective appropriate is an opportunity to look back at the previous step and think the best strategy (Choy \& Oo, 2012, p.168). This issue was strengthen by the previous research, which reflective thinking skill was able to develop student's learning process through problem based learning. Therefore, this skill important for students to achieve better performance (Angelique \& Lim, 2011, p.171).

In this research, reflective thinking skill is an activity of identifying information on a problem, considering how to solve problem and $t$ concluding it in logically way which are: (1) identifying information in mathematics problem, (2) considering the way or strategy based on information of mathematics problem, (3) selecting considered strategy, (4) evaluating problem solvingstrategy of, (5) concluding the mathematics problem logically.

Hawkins, Florian, and Rouse (2007, p. 22) states that the achievement is defined as the development of students overtime in order to enable students to perform better. Educators and communities more believe that learning is standardized by achievement test. There were several methods of measuring achievement for example; the learning outcome test which used to measure student's learning process (McCoach, Gable, \& Madura, 2013, p.3). Evans (2007, p. 24) mentions that the achievement was come from student's ability to calculate, solve problems, and how to communicate it with written test. Then, the result are measured by minimum targets and shown by the score as a indication of students success rate in learning (Feng, Fan, \& Yang, 2013 , p. 52). In this research, the achievement is one evidence of the student's competence in receiving information and follow the learning process, so that their achievement are considered important as a describe $t$ how far their ability to be achieved.

Apart to achievement and reflective thinking skill, self-regulated learning need to be developed. Zimmerman and Schunk (Effeney, Caroll, \& Bahr, 2013, p.58) states that selfregulated learning is a part of cognitive and behavior which the important aspect in learning is to confirmation how the students regulate their learning so that it give effect to academic success that formulated in numerous categories. Selfregulated learning is an attempt of students to organize themselves during learning which are to be determined not only from cognition but also the effect of environment (Zimmerman, 1989, p. $330)$. Then, Nilson (2013, p.4) says that selfregulated learning is the activities which executed by the parts of the mind. This activity require attention, self-evaluation, self-awareness, self-instrospections and open-minded for transformation of learning process.

Dignath and Buttner (2008, p. 233) explains that self-regulated learning is been viewed by students who able to regulate themselves as a metacognitive, motivation, and active on learning strategy's process. On the same side, self regulated learning defined as cognitive activity and learning constructivist which related skill and willing in learning are involved selfefficacy, metacognitive, goals, and achievement (Hadwin \& Oshige, 2011, p. 241). Zimmerman (Carneiro, Lefrere, \& Underwood, 2011, p. 5) added that self-regulated learning has several phases involved: (1) forethough, at this phase, there are task and motivation analysis include planning and aim setting, self-efficacy, estimated outcomes and task orientation, (2) performance or volitional control, in this phase, there are manage of learn strategy involve self-control that refer to self-instruction, and self-experimentation, (3) self-reflection, the students effort to evaluate learning outcomes that have been passed. In this study, self regulated learning is a process within self-awareness that be able to organize and manage the thinking that divided into planning and goal, control, and selfreflection. These aspects have indicators: (1) thoughts, statements indicating the students set goals and plan of students which include selfefficacy, self-esteem, and the ability of task orientation, (2) control, a statement indicating that students can control itself which includes 


\section{Jurnal Riset Pendidikan Matematika, 5 (2), 2018 - 256}

Diana Amirotuz Zuraida, Karyati Karyati

self-control, self-instruction, monitoring, record, and self-experimentation, (3) self-reflection, selfreflection which is fixed on methods of students learning that includes consideration of themselves, correcting with responding to the form of satisfaction or punishment regarding the development of learning, another thing that affects is the environment and way of adjusment (adaptive).

Based on the result of the pra-survey, the researchers was obtained that national exam in SMP Negeri 2 Mertoyudan in Magelang Regency has not optimal of absorption at plane solid figure indicators than the other indicators in year $2012 / 2013$ at $47,55 \%$, year $2013 / 2014$ at $55,98 \%$, year $2014 / 2015$ at $50,15 \%$, and year $2015 / 2016$ at 48,01\% (Kemendikbud, 2013, 2014, 2015, 2016). The decreased of absorption national exam in the same subject happened twice, there are in 2015 and 2016.

In addition, based on interview with one of mathematics teacher in SMP Negeri 2 Mertoyudan, Problem Based Learning setting in Numbered Heads Together and Problem Based Learning setting in Think Pair Share were never been used before so that learning process is still centered on teacher. Based on teacher's observation result, many students have a good achievement in VIII grade, however there are still have poor achievement. During the learning, teachers do not engage students in reflective and self-regulated learning. Teacher who is active provide information and the students just listen teacher's explanation. The importance of engaging students according to Walberg in behavioral, emotional, and cognitive matters can motivate students involvement. Learning models also needs to be varied so that is not always the same every time in learning takes place. Teachers should involve students at learning process so that information be able to understand about process, solve strategy, goals and benefit in the real world (Marzano, 2013, p.108).

The reflective thinking skill is less than optimal because teacher little involve students in learning. That statement is be reinforced by Herman (2007, p. 48) says that learning is not process information but the teacher guides directs the students in construct their own thoughts. Therefore, the learning is what needed which be able to link between achievement, reflective thinking skill, and self regulated learning. One of learning models which is be able to link the problem based learning (PBL). PBL is defined as a learning that focuses on the presentation of problems and then students are asked to solve problems with the student's idea based on the information provided. Steps in PBL are: (1) teacher giving orientation on issues, (2) teacher organizing students into learn groups, (3) teacher monitoring individual and grup, (4) teacher asked to presenting discussion result and evaluating them.

Arends and Kilcher (2010, p. 326) defined PBL as a student-centered approach to real-world condition structure. PBL also means studentcentered learning in which students acquire complex problem (Araz \& Sungur, 2007, p. 291). Chng, Yew, and Schmidt (2011, p. 492) stated that PBL is a learning that based on problem or issues and there are three phases should do by students: (1) problem analysis (reviewing problems together and making arguments), (2) selfdirected learning (learn to solve the problems which identified before, (3) reporting phase (presenting the result found then fixing the result so that better).

The phases of PBL stated by Farhan and Retnawati (2014, p. 231) are: (1) provide the students with a problem orientation, (2) organize the students to learn, (3) assisting an independent and group investigation, (4) develop and present the artefacts and exihibits, (5) analyze and evaluate problem-solving processes. In the same line, Arends and Kilcher (2010, p. 313) states that phases in PBL, there are: (1) presenting the problem (learning begin with presenting the problem), (2) planning the investigation (most of the PBL require students to cooperation), (3) conducting the investigation (students make answer from the problem, (4) demonstrating learning (give chance to students to show discussion's result).

The complex problems from real-world which were used to motivated students so that identifying and learning the concept. The students should solve the problem with cooperation in the small groups. At small groups, there are communication activity, gain, and integrate information with another contexts (Duch, Groh \& Allen, 2001, p. 6).

This issue shows by the study of Farhan and Retnawati (2014, p.227) which states that PBL is effective in terms of mathematics achievement, representation skill, and learning motivation. English and Kitsantas (2013, p. 145) agreed that PBL effective in terms of student's self-regulated learning. Apart of them, the study of Angkotasan (2013, p. 92) stated that PBL and cooperative learning TAI type is effective in terms of reflective thinking skill and math problem-solving. 
The problem should be solved together with cooperation and discuss. Cooperative learning is one of learning that have difference characteristics at each type. Each type provide students to mutual argued with another students. Cooperative learning make many students in the class being. This activity is useful in students academic and social (Crawford, Saul, Mathews, $\&$ Makinster, 2005, p. 48). Tsay and Brady (2010, p. 78) states that learning is often be used, one of it is cooperative learning. The learning is able to motivating students to communication and express argument throught social context. According Ebrahim (2012, p. 295), cooperative learning defines as social method that fun and engaging students in active learning, so that gave rise to influence positively such as achievement, attitudes, motivation or social interaction. Cooperative learning is another approach to develop a reflective thinking skill by observing how to obtain the information about the knowledge. In the same line, Kagan and Kagan (2009, p. 36) states that students who learn by cooperative learning better than individualistic and competitive class.

The cooperative type in this study using Numbered Heads Together (NHT) and Think Pair Share (TPS). NHT and TPS type has the same characteristics in developing thinking ability, providing opportunities for students to express opinions or ideas by communicating. NHT type has a special characteristic that is numbered which means each student has their own number in a group with different level of ability, heads together means group to solve the problem together. TPS has a characteristic think which means students are given the freedom to think individually first, then pair means students are asked to group in pairs, and share means sharing the results of discussion with other groups. TPS can facilitate students in reflective thinking so that students can express ideas conveniently (Frangenheim, 2005, p. 91).

The past study, Bahri (2015, p. 117) states that cooperative learning with TPS type in the open-ended approach effective at achievement and interest in mathematics. In addition, the study of Hardiyanto (2016, p. 167) states that PBL setting in TPS is effective in terms of student's achievement, critical thinking skill, and selfefficacy. Dewey says that reflective thinking skill is a part of critical thinking (Fisher, 2009, p. 2) and self-efficacy part of self-regulated learning (Hadwin \& Oshige, 2011, p. 241) so that PBL in TPS setting is be able to used in this study.
Phases of PBL setting NHT in this study are: (1) explain the purpose of the subject and give orientation about the problem, (2) motivate and present information, (3) organize the students into learn groups, numbered, heads, together (one grup has number on each students), (4) monitoring group learning and presenting student's work result, then call the student's number to choose who will explain discuss result in front of the class, (5) analyze and evaluate the result of group discussions on problem solving, (6) give awards and conclude the subject of learning.

phases in PBL setting TPS there are: (1) explain the purpose of the subject and give orientation about the problem, (2) motivating and presenting information, there is a process of thinking, students are given the opportunity to find answers individually, (3) organizing students into learn groups, there is a pair phase, and students are asked to group in pairs, (4) guiding group learning and presenting student work result. there is a share phase, that means the student represents discuss result, (5) analyze and evaluate the result of group discussions on problem solving, (6) give awards and conclude the subject of learning.

Based on the description of the problem and literature review, so this study aims to describe the effectiveness of problem based learning model setting of NHT and TPS type in terms of learning achievement, reflective thinking skill, and self regulated learning of students.

\section{METHOD}

This type of research was quantitative research with quasi experiment method because not all variables appear be able to controlled. This research was conducted at SMP Negeri 2 Mertoyudan, Magelang Regency, Centre Java Province, Indonesia. The population of this study is all students of slass VIII SMP Negeri 2 Mertoyudan which is divided into five classes. The sample in this study are two classes that have been choosen randomly. Random result obtained that the sample in this study is the students of class VIII-A and VIII-C SMP Negeri 2 Mertoyudan who each classes are contained 30 students. Then, re-selected randomly to determine the experiment group 1 and experiment group 2. After that, selected class VIII-A by apply the model of PBL setting NHT (experiment group 1) and class VIII C apply PBL setting TPS (experiment group 2). 
The design used in this research is pretestposttest non-equivalent group design. The design is described in Figure 1.

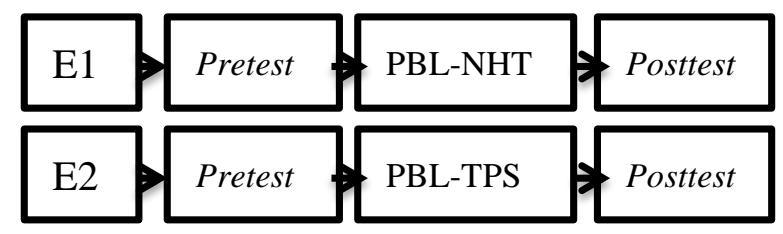

Figure 1. Design of Research (Sugiyono, 2012, p. 79)

Keterangan:

E1: Experiment group 1

E2: Experiment group 2

The process of implementation in this study are: (1) provide pretest to know the initial condition the subject, (2) then, researcher give treatment to both experiment class that is PBL setting NHT and PBL setting TPS, (3) after that, researcher gives posttest in a relatively simultaneous time, (4) researcher compared the effectivenes of PBL setting NHT and PBL setting TPS in terms of learning achievement, reflective thinking skill, and self regulated learning of students.

The data of this study were collected by tests and non-test (questionnaire) in both experimental groups. The steps taken are: (1) develop learning tools (learning implementation plan, students worksheet, pretest and posttest instrument self regulated learning (questionnaires), achievement and reflective thinking skill, (2) ask some lecturers to validate instruments research, (3) conduct test of research instruments, (4) validation of research instruments, (5) revision of research instruments (if necessary), (6) provide pretest before treatment and posttest after treatment in each group.

Validity of instruments conducted by contents validity which test instruments and questionnaire declared eligible based on the assessment of experts. The reliability of achievement test (multiple choice) is 0.64 and 0.64 with an estimated standard error measurement (SEM) of 1.72 and 1.94. The reliability of reflective thinking skill test is 0.68 and 0.43 with an estimated SEM value of 3.8 and 4.7. The reliability of self-regulated learning questionnaire is 0.77 and 0.85 with SEM value of 4.3 and 4.6.

Data analysis technique used in this study is descriptive and inferential analysis. Descriptive analysis is used to describe the situation before and after given treatments in both experiment class in terms of learning achievement, reflective thinking skill, and self-regulated learning. Description of data ensured by determining the average value, standard deviation, variance, minimum score, and maximum score of data obtained (pretest and posttest)

Effectiveness of the learning model determined by effectiveness interval. The learning achievement test data has been converted to a value between 0 to 100 . The score is included in the minimum completeness criteria (KKM) established by the school that is 75 . The reflective thinking skill data has score between 0 to 56 . The self-regulated learning questionnaires are classified according to Table 2 . The scores in the questionnaire between 27 to 108

The data is converted into form of qualitative scores with five categories. The converted using the ideal average calculation is $M_{i}=$ $\frac{1}{2}(108+27)=67.5$ and ideal deviation is $\frac{1}{6}(108-27)=13.5$. Mathematics learning in terms of self-regulated learning aspect is said to be effective if at least the average score achieved is a high category or a minimum score of 87.76.

Table 1. Category of Self Regulated Learning

\begin{tabular}{cl}
\hline Score $(\mathrm{X})$ & \multicolumn{1}{c}{ Category } \\
\hline $\mathrm{X}>94.5$ & Very High \\
$87.75<\mathrm{X} \leq 94.5$ & High \\
$82.35<\mathrm{X} \leq 87.75$ & High Enough \\
$56.7<\mathrm{X} \leq 82.35$ & Low \\
$\mathrm{X} \leq 56.7$ & Very Low \\
\hline & (Azwar, 2016, p. 163)
\end{tabular}

The data already obtained must satisfy the assumption test before being used in the inferential analysis process. The assumption test that must be encountered is normality test and homogeneity test. Normality test is encountered by using the distance of mahalanobis $\left(d_{i}^{2}\right)$ through chi square criteria $\left(X^{2}\right)$ that value $d_{i}^{2}<X^{2}{ }_{0.5(p)}$ about 50\% (Johnson \& Wichern, 2007, p. 183). Then, data were analyzed by inferential analysis. The data used is posttest data.

Inferential analysis consists of the test effectiveness by using one sample t-test with the. Test the difference in effectiveness using the Multivariate Analysis of Variance (MANOVA) $T^{2}$ HottellingI. If there is a difference of effectiveness between the two learning models, so further test independent sample t-test (Stevens, 2009, p. 147). Analysis of test data in this study assisted with SPSS 21 program. 


\section{Jurnal Riset Pendidikan Matematika, 5 (2), 2018 - 259}

Diana Amirotuz Zuraida, Karyati Karyati

\section{RESULT AND DISCUSSION}

The data have been obtained during the research are pretest and posttest of learning achievement, reflective thinking skill, selfregulated learning, and observation results of learning implementation. Data obtained from the experimental class PBL setting NHT and PBL setting TPS are described based on pretest and posttest score.

Table 2. Description Pretest and Posttest Score of Learning Achievement

\begin{tabular}{|c|c|c|c|c|}
\hline \multirow{2}{*}{ Description } & \multicolumn{2}{|c|}{ PBL-NHT } & \multicolumn{2}{|c|}{ PBL-TPS } \\
\hline & Pre & Post & Pre & Post \\
\hline Mean & 46.27 & 74 & 46.4 & 73.47 \\
\hline $\begin{array}{l}\text { Standard } \\
\text { Deviation }\end{array}$ & 12.6 & 12.42 & 10.37 & 13.76 \\
\hline Min (Ideal) & 0 & 0 & 0 & 0 \\
\hline Min & 16 & 44 & 24 & 36 \\
\hline $\operatorname{Max}$ & 100 & 100 & 100 & 100 \\
\hline Max Score & 64 & 92 & 64 & 92 \\
\hline Variance & 158.55 & 154.21 & 107.7 & 189.22 \\
\hline
\end{tabular}

Based on the result of descriptive statistics analysis in Table 2, the mean score of mathematics learning achievement in both classes before given treatment is almost the same that is 46.27 with variance 158.55 and 46.4 with variance 107.7 in the low category. After treatment, the mean score of class that applied the PBL with setting increase 27.73 point. While, the mean score of class applied PBL setting TPS increased 27.07 point.

Table 3. Description Pretest and Posttest Score of Reflective Thinking Skill

\begin{tabular}{lcccc}
\hline \multirow{2}{*}{\multicolumn{1}{c}{ Description }} & \multicolumn{2}{c}{ PBL-NHT } & \multicolumn{2}{c}{ PBL-TPS } \\
\cline { 2 - 5 } & Pre & Post & Pre & Post \\
\hline Mean & 4.53 & 34.1 & 4.73 & 34.8 \\
Standard Deviation & 4.6 & 6.2 & 4.7 & 6.5 \\
Min (Ideal) & 0 & 0 & 0 & 0 \\
Min Score & 0 & 24 & 0 & 26 \\
Max (Ideal) & 56 & 56 & 56 & 56 \\
Max Score & 15 & 50 & 14 & 51 \\
Variance & 21.2 & 38.44 & 22.1 & 42.2 \\
\hline
\end{tabular}

Based on the results of descriptive statistics analysis in Table 3, the mean score of reflective thinking skill of students in two classes before given treatment is almost the same that is 4.53 with variance of 21.2 and 4.73 with variance 22.1 in the very low category. After treatment, the mean score of class PBL setting NHT is 34.1 and class applied the PBL setting TPS is 34.8 . The mean score of class that applied PBL setting NHT increase 23.2 point and the class that applied PBL setting TPS increase 30.07 .
Table 4. Description Pretest and Posttest Score of Self-Regulated Learning

\begin{tabular}{lcccc}
\hline \multirow{2}{*}{ Description } & \multicolumn{2}{c}{ PBL-NHT } & \multicolumn{2}{c}{ PBL-TPS } \\
\cline { 2 - 5 } & Pre & Post & Pre & Post \\
\hline Mean & 76.1 & 76.23 & 72.23 & 72.6 \\
Standard & 9.24 & 9.6 & 8.5 & 13.6 \\
Deviation & 27 & 27 & 27 & 27 \\
Min (Ideal) & 61 & 60 & 57 & 38 \\
Min Score & 108 & 108 & 108 & 108 \\
Max (Ideal) & 94 & 94 & 87 & 92 \\
Max Score & 85.42 & 92.18 & 72.18 & 184.5 \\
Variance & & & & \\
\hline
\end{tabular}

Table 4 shows that the mean score of selfregulated learning students in two classes before given treatment is 76.1 with variance of 85.42 in the high category and 73.23 with variance of 72.18 in the medium category. After treatment, the mean of class PBL setting NHT class is 76.23 and the mean of class PBL setting NHT class is 72.6 .

.Normality and homogeneity test of pretest and posttest data on learning achievement, reflective thinking skill, and self-regulated learning has been presented in Table 5 .

Table 5. Result of Normality Test

\begin{tabular}{ccc}
\hline Class & $\begin{array}{c}d_{i}^{2} \text { Before } \\
\text { Treatment }\end{array}$ & $\begin{array}{c}d_{i}^{2} \text { After } \\
\text { Treatment }\end{array}$ \\
\hline PBL- NHT & $50 \%$ & $50 \%$ \\
PBL- TPS & $70 \%$ & $50 \%$ \\
\hline
\end{tabular}

Table 5 shows that reached to $50 \%$ of data has a value $d_{i}^{2}<X^{2}{ }_{0.5(p)}$ on pretest and posttest at PBL setting NHT class and PBL setting TPS class reached to $70 \%$. All of posttest (after treatment) reached $50 \%$. It can be said that the data has a normal distribution. The result of homogeneity test can be seen in Table 6 .

Table 6. Result of Homogeneity Test

\begin{tabular}{ccc}
\hline & Before Treatment & After Treatment \\
\hline Box's $M$ & 6.627 & 12.525 \\
$F$ & 1.042 & 1.970 \\
Sig & 0.395 & 0.066 \\
\hline
\end{tabular}

Table 6 shows that the significance of Box's M value is more than 0.5 . It can be said that multivariat homogeneity assumptions are completed for pretest and posttest data. The result of learning effectiveness test of PBL setting NHT and PBL setting TPS in terms of learning achievement, reflective thinking skill, and self regulated learning can be seen in Table 7 .

According to the Table 7, it is found that PBL setting NHT have significance value of $t$ for all aspects more than 0.05 , so $H_{0}$ is accepted, 


\section{Jurnal Riset Pendidikan Matematika, 5 (2), 2018 - 260}

Diana Amirotuz Zuraida, Karyati Karyati

which means the learning of PBL setting NHT is not effective in terms of learning achievement, reflective thinking skill, and self regulated learning. Furthermore, it was obtained that the PBL setting TPS has significance $t$ value for all aspects more than 0.05 except for reflective thinking skill. This indicates that the decision of $H_{0}$ accepted which means that the learning of PBL setting TPS is not effective in terms of learning achievement and self-regulated learning, but effective in terms of reflective thinking skill

Table 7. Result of One Sample t-test

\begin{tabular}{lcccc}
\hline \multirow{2}{*}{ Aspect } & \multicolumn{2}{c}{ PBL-NHT } & \multicolumn{2}{c}{ PBL - TPS } \\
\cline { 2 - 5 } & $t$ & Sig & $t$ & Sig \\
\hline Achievement & -0.441 & 0.332 & -0.611 & 0.273 \\
Reflective & 1.263 & 0.108 & 1.768 & 0.044 \\
SRL & 1.131 & 0.133 & -0.665 & 0.256 \\
\hline
\end{tabular}

Both of PBL setting NHT and PBL setting TPS classes are ineffective in terms of selfregulated learning. In the univariate hypothesis test, the significance value of both PBL setting NHT and PBL setting TPS classes was 0.133 and 0.256 which it was more than the significance value 0.05 . The ineffectiveness of both groups is caused by several factors. First, the learning time was cut off because there are other activities that used the schedule of mathematics learning. Second, for several days, the schedule of mathematics learning was shortened so that researcher has 30 minutes for each section of mathematics learning in the class. Third, the mastery of geometry's subject (plane solid figure) was lower than other subject material in SMP Negeri 2 Mertoyudan. This issue indicated by the result of national exam from 2013 to 2016 that was 47.55\%; 55.98\%; 50.15\%; $48.01 \%$.

The next of data analysis results was PBL setting TPS is effective in terms of reflective thinking skill but not effective in terms of learning achievement and self-regulated learning. In one sample $t$-test data analysis showed that $t$ value for reflective thinking skill in PBL setting TPS is 1.768 with significance to 0.044 . Similarly, Angelique and Lim's (2011, p. 171), the study found that students with reflective thinking skill developed from habitual activities using PBL model. In addition, this type of TPS is characterized by paired group and there is a phase of think, pair, share (Arends \& Kilcher, 2010, p. 314). Students are given time to think individually to find the answers themselves, then in pairs to discuss answers that have been obtained from the results of individual thinking, and students represent groups in pairs to present the result of the discussion in front of the class.

Grouping in pairs makes them flexible without having move from the seat. In addition, they are easier to communicate or express their ideas with on another and freely choose a partner in the discussion. Participation in thinking equivalent on the TPS type. It makes possible for students to practice reflective thinking skill.

PBL setting TPS is not effective in terms of learning achievement and self-regulated learning. This result was showed by the analysis of one sample $t$-test with $t$ values of -0.611 and 0.665 significance of 0.273 and 0.256 . PBL setting TPS is not effective in terms of learning achievement and self-regulated learning because in the group, many students hang their work to the other friends so that equal participation in pairs become unequal. Students also feel that the lack of time to discuss in the group. This issue contrary to Hardiyanto (2016, p. 167) which stated that PBL setting TPS is effective in terms of learning achievement and self-efficacy.

In addition, PBL setting NHT is not effective in terms of reflective thinking skill and learning achievement. This is indicated by the analysis of one sample $t$-test with $t$ value of 1.263 and -0.441 . The significance was 0.108 and 0.332 . The value of significance is still more than 0.05. The ineffectiveness of PBL setting NHT in terms of reflective thinking skill was due to the lack of communication between students in a equivalent group.

Students in one group of participants were not equal because that was not all group members are active to solve the problems given on student's worksheet. So that communication in the group was lacked. Students feel irresponsible for group work. This issue contrary to the study of Angkotasan (2013, p. 161) which stated that PBL was effective in terms of reflective thinking skill and Bahri (2015, p. 117) which stated that cooperative learning of TPS and NHT types was effective in terms of mathematics learning achievement.

The results analysis of difference of effectiveness of learning between PBL setting NHT and PBL setting TPS in terms three variables using $T^{2}$ Hottelling can be seen in Table 8. Based on Table 9, there is information that significance value of $F$ was 0.572 , it was more than the significance value 0.05 . It means that there is no difference effectiveness between experimental class of PBL setting NHT and PBL setting TPS in terms of learning achievement, 
reflective thinking skill, and self-regulated learning. The first condition of class for all measured aspects was the same. Furthermore, in the data after treatment there was information that the value significance was 0.622 more than 0.05 . It means after treatment there is no difference effectiveness in learning achievement, reflective thinking skill, and self regulated learning between classes that applied PBL setting NHT and PBL setting TPS.

Table 8. Result of $T^{2}$ Hottelling Before and After Treatment

\begin{tabular}{ccc}
\hline & F & Sig \\
\hline Before Treatment & 0.673 & 0.572 \\
After Treatment & 0.594 & 0.622 \\
\hline
\end{tabular}

\section{CONCLUSIONS}

Based on the results of hypothesis testing and discussion that has been described previously, it can be obtained the following conclusions: (1) PBL setting NHT on the subject plane solid figure of SMP VIII grade is not effective in terms of mathematics learning achievement, reflective thinking skill, and self-regulated learning students, (2) the learning of PBL setting TPS type for SMP VIII grade is ineffective in terms of mathematics learning achievement and self regulated learning but effective in terms of reflective thinking skill, (3) there Is no difference of effectiveness between PBL with setting cooperative NHT type and PBL with setting cooperative TPS type in terms of mathematics learning achievement, reflective thinking skill, and self regulated learning of students at plane solid figure matter.

Suggestions for future researchers are: (1) conducting research on different subjects or materials to see the benefits of applying PBL with setting cooperative TPS type in terms of reflective thinking skill, (2) providing additional interesting learning media so that students are motivated to generate ideas, (3) conduct a study that examines the effectiveness of PBL learning with setting cooperative NHT type and PBL learning with setting cooperative TPS type using different dependent variables to provide more indepth information on the effectiveness of PBL with setting cooperative NHT and TPS types, and (4) select the research time at the beginning or middle of the even or odd semester so that is not divided in time with the preparation of the national exam.

\section{REFERENCES}

Angelique, L., \& Lim, Y. L. (2011). A comparison of students reflective thinking across different years in a problem based learning environment. Intructional Science, 39, 171-188.

Angkotasan, N. (2013). Model PBL dan cooperative learning tipe TAI ditinjau dari aspek kemampuan berpikir reflektif dan pemecahan masalah matematis. Pythagoras: Jurnal Pendidikan Matematika, $\quad$ 8(1), 92-100. doi:https://doi.org/10.21831/pg.v8i1.8497

Araz, G., \& Sungur, S. (2007). The interplay between cognitive and motivational variables in a problem based learning environment. Learning and Individual Differences, 17, 291-297.

Arends, R. I., \& Kilcher, A. (2010). Teaching for student learning. London, UK: Routledge

Azwar, S. (2016). Tes prestasi: Fungsi dan pengembangan pengukuran prestasi belajar. Yogyakarta: Pustaka Pelajar.

Bahri, S. (2015). Keefektifan model pembelajaran kooperatif tipe think pair share dan numbered heads together dengan pendekatan open ended ditinjau dari prestasi belajar geometri dan minat belajar matematika siswa SMA. Thesis, Universitas Negeri Yogyakarta, Yogyakarta.

Carneiro, R., Lefrere, K. S., \& Underwood, J. (2011). Self-regulated learning in technology enhanced learning environment. Rotterdam, Netherland: Sense Publisher.

Chng, E., Yew, E. H. J., \& Schmidt, H. G. (2011). Effect of tutor-related behaviors on the process of problem-based learning. Advanced in Health Science Education, 16, 491-503.

Choy, S. E., \& Oo, P. S. (2012). Reflective thinking and teaching practices: a precursor for incorporating critical thinking into the classroom? International Journal of Instruction, 5(1), 167-182.

Crawford, A., Saul, W., Mathews, S. R., \& Makinster, J. (2005). Teaching and learning strategies for the thinking classroom. New York, NY: The International Debate Education Association. 
Dignath, C., \& Buttner, G. (2008). Components of fostering self-regulated learning among students: A meta-analysis on intervention studies at primary and secondary school level. Metacognition Learning, 3, 231264.

Duch, B. J., Groh, S. E., \& Allen, D. E. (2001). Apractical "how to" for teaching undergraduate courses in any dicipline: The power of problem-based learning. Sterling, VA: Stylus Publishing.

Ebrahim, A. (2012). The effect of cooperative learning strategies on elementary students' science achievement and social skills in Kuwait. International Journal of Science and Mathematics Education, 10(2), 293314.

Effeney, G., Caroll, A., \& Bahr, N. (2013). Self regulated learning: Key strategies and their sources in a sample of adolescent males. Australian Journal of Educational and Developmental Psychology, 13, 58-74.

English, M. C., \& Kitsantas, A. (2013). Supporting student self-regulated in problem and project based learning. Interdiciplinary Journal of Problem-Based Learning, 7(2), 128-150.

Evans, B. (2007). Student attitudes, conceptions, and achievement in introductory undergraduate college statistics. The Mathematics Educator, 17(2), 24-30.

Farhan, M., \& Retnawati, H. (2014). Keefektifan PBL dan IBL ditinjau dari prestasi Belajar, kemampuan representasi matematis, dan motivasi belajar. Jurnal Riset Pendidikan Matematika, 1(2), 227-240. doi:10.21831/jrpm.v1i2.2678

Feng, H. Y., Fan, J. J., \& Yang, H. Z. (2013). The relationship of learning motivation and achievement in EFL: Gender as an intermediated variable. Educational Research of International, 2(2), 50-58.

Fisher, A. (2009). Berpikir kritis: Sebuah pengantar. (Terjemahan Benyamin Hadinata). Jakarta: Gelora Aksara Pratama.

Foster, C. (2016). Confidence and competence with mathematical procedure. Education Studies in Mathematics, 91(2), 271-288.

Frangenheim, E. (2005). Reflections on classroom thinking strategies. London, UK: Paul Chapman Publishing.
Hadwin, A., \& Oshige, M. (2011). Selfregulation, coregulation, and socially shared regulation: Exploring perspectives of social in self-regulated learning theory. Teacher College Record, 113(2), 240-264.

Hardiyanto, W. (2016). Efektivitas problembased learning (PBL) setting model kooperatif tipe think talk write (TTW) dan think pair share (TPS) ditinjau dari prestasi belajar, kemampuan berpikir kritis, dan self-efficacy siswa kelas VIII pada pembelajaran geometri. Thesis, Universitas Negeri Yogyakarta, Yogyakarta.

Hawkins, K. B., Florian, L., \& Rouse, M. (2007). Achievement and inclusion in schools. New York, NY: Routledge.

Herman, T. (2007). Pembelajaran berbasis masalah untuk meningkatkan kemampuan berpikir matematis tingkat tinggi siswa sekolah menengah pertama. Educationist, 1(1), 47-56.

Johnson, R. A., \& Wichern, D. W. (2007). Applied multivariate statistical analysis. Upper Saddle River, NJ: Pearson Prentice Hall.

Kagan, S., \& Kagan, M. (2009). Kagan cooperative learning. San Clemente, CA: Kagan Publishing.

Kementerian Pendidikan dan Kebudayaan Republik Indonesia. (2013). Laporan hasil dan statistik nilai ujian nasional tahun pelajaran 2012/2013. Jakarta: Kemendikbud.

Kementerian Pendidikan dan Kebudayaan Republik Indonesia. (2014). Laporan hasil dan statistik nilai ujian nasional tahun pelajaran 2013/2014. Jakarta: Kemendikbud.

Kementerian Pendidikan dan Kebudayaan Republik Indonesia. (2015). Laporan hasil dan statistik nilai ujian nasional tahun pelajaran 2014/2015. Jakarta: Kemendikbud:

Kementerian Pendidikan dan Kebudayaan Republik Indonesia. (2016). Laporan hasil dan statistik nilai ujian nasional tahun pelajaran 2015/2016. Jakarta: Kemendikbud.

Kementerian Pendidikan dan Kebudayaan Republik Indonesia. (2016). Peraturan Menteri Pendidikan dan Kebudayaan RI 


\section{Jurnal Riset Pendidikan Matematika, 5 (2), 2018 - 263}

Diana Amirotuz Zuraida, Karyati Karyati

Nomor 21, tahun 2016, tentang standar isi pendidikan dasar dan menengah.

Marzano, R. J. (2013). Seni dan ilmu pengajaran. (Terjemahan Rahmat Purwono). Jakarta: Indeks.

McCoach, D. B., Gable, R. K., \& Madura, J. P. (2013). Instrument development in the affective domain. London, UK: Springer.

National Council of Teachers of Mathematics. (2000). Principles and standards for school mathematics. Reston, VA: Author.

Nilson, L. B. (2013). Creating self-regulated learners: Strategies to strengthen students' self-awareness and learning skills. Sterling, VA: Stylus Publishing.

Rodgers, C. (2002). Defining reflection: Another look at John Dewey and reflective thinking. Teachers College Record, 104(4), 842-866.

Singh, K., Granville, M., \& Dika, S.,(2002), Source mathematics and science achievement: effects of motivation, interest, and academic engagement. The Journal of Educational Research, 95(6), 323-332.

Stevens, J. (2009). Applied multivariate statistics for the social science. New York, NY: Routledge

Sugiyono. (2012). Metode penelitian kuantitatif, kualitatif, dan $R \& D$. Bandung: Alfabeta

Tsay, M., \& Brady, M. (2010). A case study of cooperative learning and communication pedagogy does working in teams make a differences? Journal of the Scholarship of Teaching and Learning, 10(2), 78-89.

Weast, D. (1996). Alternative teaching strategies: the case for critical thinking. Teaching Sociology, 24(2), 189-194.

Zimmerman, B. J. (1989). A social cognitive view of self-regulated academic learning. Journal of Educational Psychology, 81(3), 329-339. 